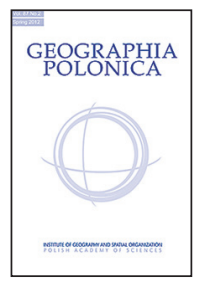

\title{
TWO DIMENSIONAL MODELLING OF THE FLOOD ZONES IN THE VISTULA RIVER VALLEY IN WARSAW
}

\author{
ARTUR MAGNUSZEWSKI *, MAŁGORZATA GUTRY-KORYCKA *, MICHAŁ SZYDŁOWSKI * * \\ * University of Warsaw, Hydrology Department, \\ Krakowskie Przedmieście 30, 00-927 Warszawa, Poland \\ E-mails: asmagnus@uw.edu.pl; msgutryk@uw.edu.pl \\ ** Gdańsk University of Technology, Faculty of Civil and Environmental Engineering, \\ Narutowicza 11/12, 80-952 Gdańsk, Poland \\ E-mail: michal.szydlowski@pg.gda.pl
}

\begin{abstract}
When estimating the reach of the flood zones, a mathematical model that describes the flood wave propagation, as well as the digital elevation models can be used. In this study, a two step approach has been applied. In the first step, in order to find the most relevant flooding areas, a one dimensional hydraulic model HEC-RAS has been used, which assumes steady state flow conditions and a discharge of $Q_{\mathrm{p}} 1 \%=7210 \mathrm{~m}^{3} / \mathrm{s}$ and $Q_{\mathrm{p}} 0.1 \%=9960 \mathrm{~m}^{3} / \mathrm{s}$. The segment of the Vistula Valley analysed is $47.05 \mathrm{~km}$ long. In the second step, a smaller area has been analysed using the 2D hydraulic model of shallow water flow which is based on the Roe scheme of finite volume method.
\end{abstract}

Key words: Warsaw, Vistula River, flood zone maps, inundation modelling

\section{INTRODUCTION}

Large cities have historically been disproportionately well protected against floods, which has been a reflection of their power. Urban flood disasters were significantly reduced because of the establishment of low dikes at the beginning of the nineteenth century, but urban areas grew and their infrastructure became more consolidated during the twentieth century. There is a tendency for low density suburbs to spread near European cities, including onto floodplains. Another factor is the shift in the location of industries, with many export oriented companies looking for a location downstream of floodplains, especially along navigable waterways, like, for example, London, Roterdam, the Hague and Le Havre. Furthermore, old river cities are experiencing changes when it comes to flood hazard potential as a result of redevelopment projects that focus on making waterfront areas more attractive. Some good examples of these include London, Manchester, Berlin, Hamburg, Warsaw, where neglected and outdated buildings have been replaced by new up-market apartments, cultural facilities, university and government offices (Mitchell 2003). Low value investments are replaced by those of higher value, located in flood hazard zones.

In Poland the creation of flood hazard maps was required by Article 82 of the Water Act that came into force from 18 July 2001. It calls for the creation of flood hazard maps 
for both areas that are unprotected and those that are protected by dikes further down the major rivers. Flood maps (referred to as flood risk maps) are created for planning purposes or for the needs of insurance companies. In practice, the Polish water authorities responsible for flood protection in the upper parts of the Oder and Vistula Rivers have delineated two types of flood zones (Drożdżal 2006). First is a direct risk zone which corresponds with the riparian area, and it also covers those places where flood protective dikes are not high enough to contain the flood. The second type is zones of potential risk where if the flood dikes were to be breached, this would lead to the inundation of the protected floodplain area. The information about potential flooding must contain data like:

- the time of the flood wave arrival at some characteristic points of the inundated area,

- extreme water depth, and velocity in the flooded area,

- the duration and range of the flooding. Within those direct risk flood areas that are most vulnerable, construction of permanent buildings is forbidden. In zones of potential flooding it is assumed that during inundation water flows with a slower velocity and is not as deep, which is why construction is allowed in this zone, under certain conditions.

The magnitude of a flood is usually expressed in terms of the probability or of the return period. For example, in the upper reaches of the Vistula River the flood maps for unprotected areas are made for discharges with a probability of $\mathrm{p}=50 \%, 20 \%, 10 \%$, $5 \%, 3.33 \%, 1 \%, 0.2 \%$; and for dike protected areas of $\mathrm{p}=1 \%, 0.2 \%$ (Grela et al. 2006). With the spatial data that is available today, the visualization of the flood reach is usually made on the digital elevation models and maps of ortophotomaps. The elevation of flood waters is obtained from water stage observations or mathematical models of flood wave propagation. Polish legislation does not specify the mathematical models or numerical tools needed to simulate the flood wave propagation for flood hazard mapping. However, some suggestions can be found in the
Polish literature (Nachlik et al. 2000; Radczuk et al. 2001). Software that can be used for this purpose shows that the complexity of the mathematical models vary from the one dimensional Bernoulli steady flow equation and the Saint-Venant unsteady flow equations (for example in HEC-RAS and MIKE 11 computation systems) to the two dimensional depth averaged Navier-Stokes in unsteady shallow water flow equations (MIKE 21, NCCHE2D, WOLF).

\section{STUDY SITE DESCRIPTION}

The creation of the Vistula Valley near Warsaw was a consequence of the fluvial processes taking place during the Quaternary at the final stages of the last glaciation and the Holocene. The width of lowest over-flood terrace varies from between some $6 \mathrm{~km}$ in the area of the Praga district, to just several dozen meters on the left bank in the area of the Old Town. The beginning of the river training works in the Vistula River channel dates back to the catastrophic flood of July 1884 and the beginning of the construction of the water uptake for the city water supply system. In the years 1893-1910 the river training work was conducted along both banks of the river. It was assumed that the width of the regulation route of the river was $340 \mathrm{~m}$. Then, in the years 1923-1931, further regulation work was carried out, with the purpose of protecting the shores and the dikes that had recently been built in 1924.

Immediately after World War II the river channel of the Vistula in Warsaw became a dumping ground for debris. This caused the high-discharge cross sections in some areas to be reduced by $50 \%$ in comparison with the middle Vistula, forming the so-called Warsaw "corset" along the segment of 507-517 $\mathrm{km}$. A little further upstream of the ŚlackoDąbrowski Bridge the channel of the Vistula becomes narrower to approximately $350 \mathrm{~m}$. Such a significant narrowing of the channel in the entire middle and lower course of the river is unique. 
As a result of the training works, in the years 1921-1953 the channel bottom ordinate decreased on average by $15 \mathrm{~cm}$ per annum, and in the following years 1953-1959 it decreased as much as $9 \mathrm{~cm}$ per annum (Bogdanowicz et al. 2000). The narrowing of the high discharge channel caused an increase in the range of the water stages, and an increase in the water flow velocity and its eroding force.

According to the designs of the Central Water Management Bureau, from the 1960s onwards the flood defences were designed to protect the city against a flood that has a frequency of once every thousand years $\left(Q_{\mathrm{p}} \quad 0.1 \%\right)$ with the protection dikes set at a distance of 400-600 m. Outside of Warsaw, upstream and downstream, the protection dikes are set at a distance of 1000-1700 m and shield agricultural areas against the inundation caused by a flood of $Q_{\mathrm{p}} 1 \%$.

The mean annual discharge of the Vistula at the profile of the Warsaw Haven in the years 1951-1995 was $561 \mathrm{~m}^{3} / \mathrm{s}$. The largest flood in the 19th century occurred in 1813, when the lowest parts of the town were inundated, as well as the suburban areas between Wilanów and Kazuń. The highest discharge measured during the March 1924 flood was $5860 \mathrm{~m}^{3} / \mathrm{s}$. The $Q_{\mathrm{p}} 1 \%$ discharge, is 7210 $\mathrm{m}^{3} / \mathrm{s}$, which is an estimate taken from the data covering the period 1921-1997 (Wierzbicki 2001). Fal and Dąbrowski (2001) established, on the basis of the 200 year series of maximum water levels and the archival discharge curve, that the $Q_{\mathrm{p}} 0.1 \%$ discharge is equal to $9,960 \mathrm{~m}^{3} / \mathrm{s}$.

\section{METHOD}

Recently there have been a number of studies on the flooding of urban areas (Hański et al. 2006; Mark et al. 2004; Dewals et al. 2002; Haider et al. 2003; Chen et al. 2005; Sole and Zuccaro 2005). The common practice has been the application of one hydrodynamic model, which results in the form of water surface elevations, which are then compared with the digital elevation model (DEM).
In our study, the two step approach has been applied. For practical reasons (the time of computation) in the first step, in order to find the most relevant flooding areas, a one dimensional hydraulic model HEC-RAS (US Army Corps of Engineers Hydrologic Engineering Center) has been used. In the study, the calculation was made by assuming the existence of steady state flow conditions and a discharge of $Q_{\mathrm{p}} 1 \%=7,210 \mathrm{~m}^{3} / \mathrm{s}$ and $Q_{\mathrm{p}} 0.1 \%=9,960$ $\mathrm{m}^{3} / \mathrm{s}$; energy losses were evaluated by a friction equation (Manning's). The segment of the Vistula Valley that was analysed encompasses the stretch from the vicinity of Józefów down to Lawice Kiełpińskie, which has a length of $47.05 \mathrm{~km}$ (i.e. between 494.76 and 541.81 $\mathrm{km}$ of the river course). DEM data has been compiled from various sources, including echo sounder measurements carried out from 24 to 30 September 1998 on the reach of the Vistula River between 490.760 and 541.800 $\mathrm{km}$, photogrametric derived elevation data of the floodplain area provided by the District Geodesic and Cartographic Department, and data for the area behind the dikes provided by the Office of the Surveyor of the Mazowieckie Voivodship. The elevation data were merged into one file containing around 0.77 million points, and a raster digital model of relief (DEM) with a resolution of $20 \times 20 \mathrm{~m}$ was interpolated with a procedure of inverse distances. The Manning roughness coefficient values were estimated on the basis of land use maps and air photographs for the area between the dikes. The following values of the roughness coefficient were adopted: the channel of the Vistula River, 0.03; meadows, 0.04; single trees, 0.045; arable land, 0.05; orchards, 0.055 ; forests, 0.12 ; osiers and bushes, 0.15 ; roads and boulevards, 0.02 . These values of the roughness coefficients have been found in a previous study (Soczyńska et al. 2002), and verified during model calibration, in order to match up the water table ordinates obtained from HEC-RAS calculations to field measurements from 1998 (Wierzbicki 2001).

Flood zone ranges for the discharge $Q_{\mathrm{p}} 1 \%$ and $Q_{\mathrm{p}} 0.1 \%$ have been obtained by imposing the water table models on the DEM using the map algebra function of ILWIS 3.3 software 
(Gutry-Korycka et al. 2006). In present conditions, the elevations of flood protection dikes are sufficient to convey the $Q_{\mathrm{p}} 1 \%$ discharge. Were the $Q_{\mathrm{p}} 0.1 \%$ discharge to occur the dikes would not guarantee the protection of an important part of the city. From that analysis, three flood risk areas have been selected that represent the districts of Łomianki, Saska Kępa and Wilanów (Fig. 1).

In the second stage, a smaller area has been analyzed using the 2D hydraulic model developed by Szydłowski (2001). It is a model of shallow water flow solved using the Roe scheme of the finite volume method. The numerical algorithm was prepared and tested in order to simulate the flood wave propagation that results from dam break events in natural river valleys (Szydłowski 2003) and which are then adapted to allow them to flow in urban areas (Szydłowski 2005).

There is always some level of uncertainty in potential flood modelling when it comes to the selection of dikes' breach points. We have taken into consideration river channel morphology, the orientation of the current and the dikes, and the pattern of flood related forms on the floodplain behind the dikes.

To represent the relief in the vicinity of the dike breach a triangular irregular computational mesh has been used, which allows local densification in the area of special interest. Additional data for calculation include the dike crest elevation, and the elevation of the water level in the channel at a given flood magnitude. It has been assumed that the dike breach has a width of $100 \mathrm{~m}$ and a depth that is immediately equal to the height of the dike. This simplification is justified when one bears in mind the dimension of the whole area represented in the model.

There is another problem that is related to the representation of single buildings in the model. The computational mesh is coarse, so these objects cannot be represented as islands around which water flows while they are not inundated. If we try to include the elevations of the buildings to the DEM and use it as input data for the hydrodynamic model, then we encounter the problem of local, extremely steep bed gradients, which leads to numeri- cal instability in the computation. Due to this limitation it has been decided to represent the larger blocks of buildings by the assignment of a proper Manning roughness coefficient.

\section{RESULTS}

Our first results obtained from the 1D model, which shows the range of the potential flood zone, are different from previous studies that have been undertaken by Jacewicz (2000), and are better fitted to the floodplain morphology. The accuracy of our calculations is enhanced mainly because of the more realistic representation of the river channel morphology and the floodplain relief. Then, if we compare the flood range obtained from the $2 \mathrm{D}$ model, it is evident that the one dimensional approach based on water level extrapolation does not take into consideration the principle of mass conservation. Areas that have local depressions, like oxbows and paleochannels, store water and this results in a smaller area of inundation.

The results for the segment of the channel between 514 and $515.5 \mathrm{~km}$ on the righthand bank indicate a threat to the Zoological Garden, which is protected by a dike whose height is inadequate. Likewise, Praga Haven and its hinterland are not properly protected against the $Q_{\mathrm{p}} 1 \%$ water. Entry to the port ought to be closed off by a flood gate, if more intense construction activity in this area is to be undertaken. Were the $Q_{\mathrm{p}} 0.1 \%$ discharge to occur, the dikes would not ensure protection of an important part of the city, especially on the right bank, which covers the segments of $512.5-521 \mathrm{~km}$ and $523-535 \mathrm{~km}$; and on the left bank, the segments of $525-533.5 \mathrm{~km}$. The area down-stream of $526 \mathrm{~km}$ is a non-urban area, and so the potential flood losses are lower than in the case of more clearly defined urban areas. The greatest concern is caused by the situation on the left bank segment between 511 and $514 \mathrm{~km}$, which is not protected by the dikes at all, while the elevation of the artificially raised flood terrace does not secure the safe passage of the Qp $0.1 \%$ waters. At the same time, this area is attractive for potential investment projects within Powiśle 


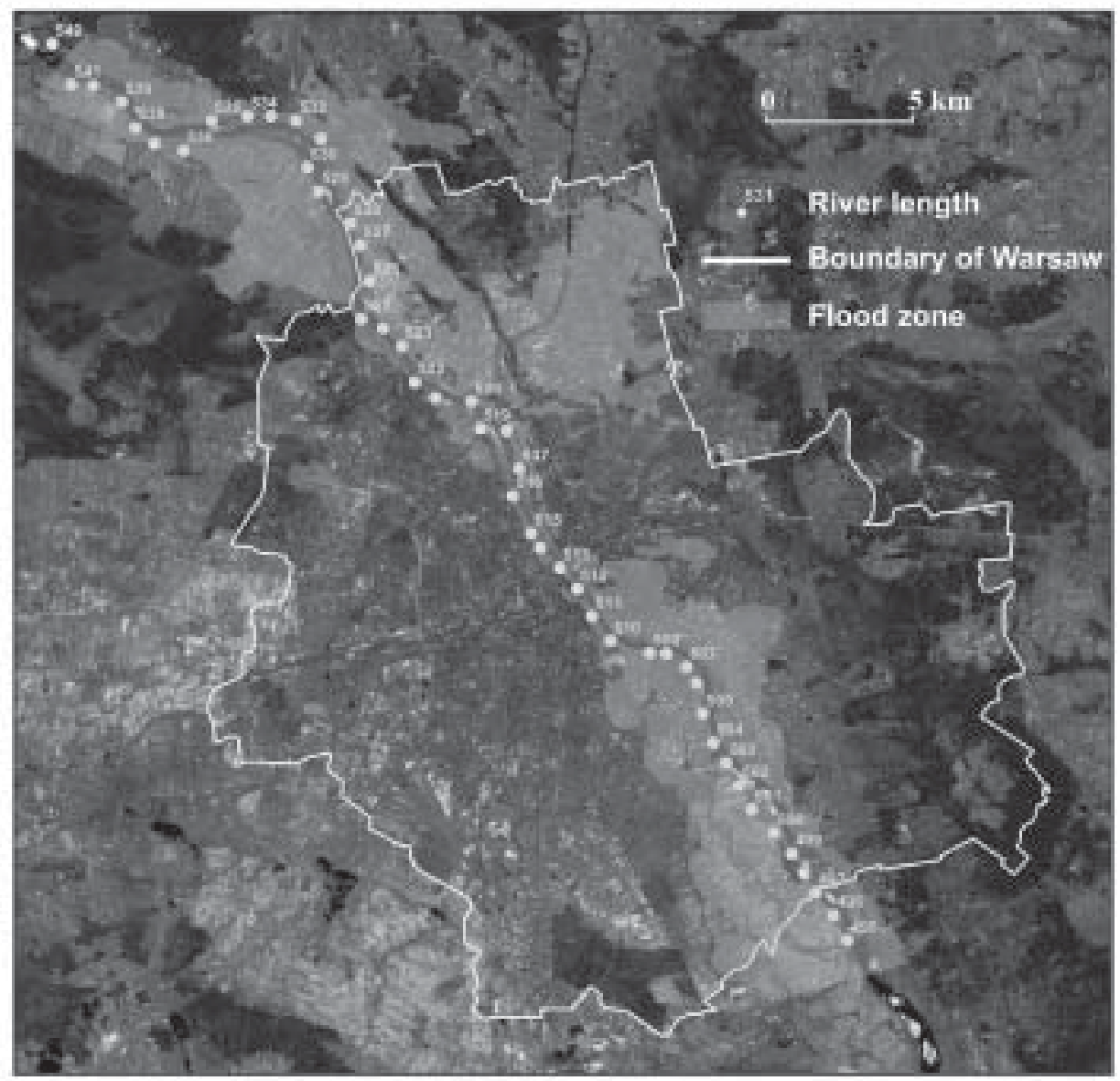

Figure 1. Flood zone of $Q_{\mathrm{p}} 1 \%$ probability in Warsaw obtained from the DEM and HEC-RAS models; selected potential flood zones of Łomianki (1), Saska Kępa (2) and Wilanów (3).

district, including extensions to the University of Warsaw's campus. A similar situation exists along the segment between 517 and $521 \mathrm{~km}$, where in an area directly adjacent to the river, the Olympic Centre was established and further developments are planned. Beyond that there is a very sensitive area, the $510-511 \mathrm{~km}$ fragment of the left bank, where the flood dikes end, and the entry to the area behind the dikes is protected by the flood gate at the Czerniaków Head. Other stretches of the river, where there is a risk that the Qp $0.1 \%$ waters might overflow the dikes, are the $517-521 \mathrm{~km}$ segment on the left bank and 512-523 km segment on the right bank.
The 2D model for the selected three areas has been run for a flood $Q_{\mathrm{p}} 1 \%$, and the results of the model in time steps of 15,30 minutes, $1,3,6,12$ hours, have been stored in files. The parameters that have been stored include water level elevation, magnitude and the velocity vector. The results of the model have been represented in a tabular form, and have been converted into a cartographic representation in the ILWIS 3.3 program. This form of the data is used for visualization and the calculation of statistics that represent the inundated area of the potential flood $Q_{\mathrm{p}} 1 \%$ (Fig. 2 a-c).

The information about the inundation of separate buildings has been obtained by 


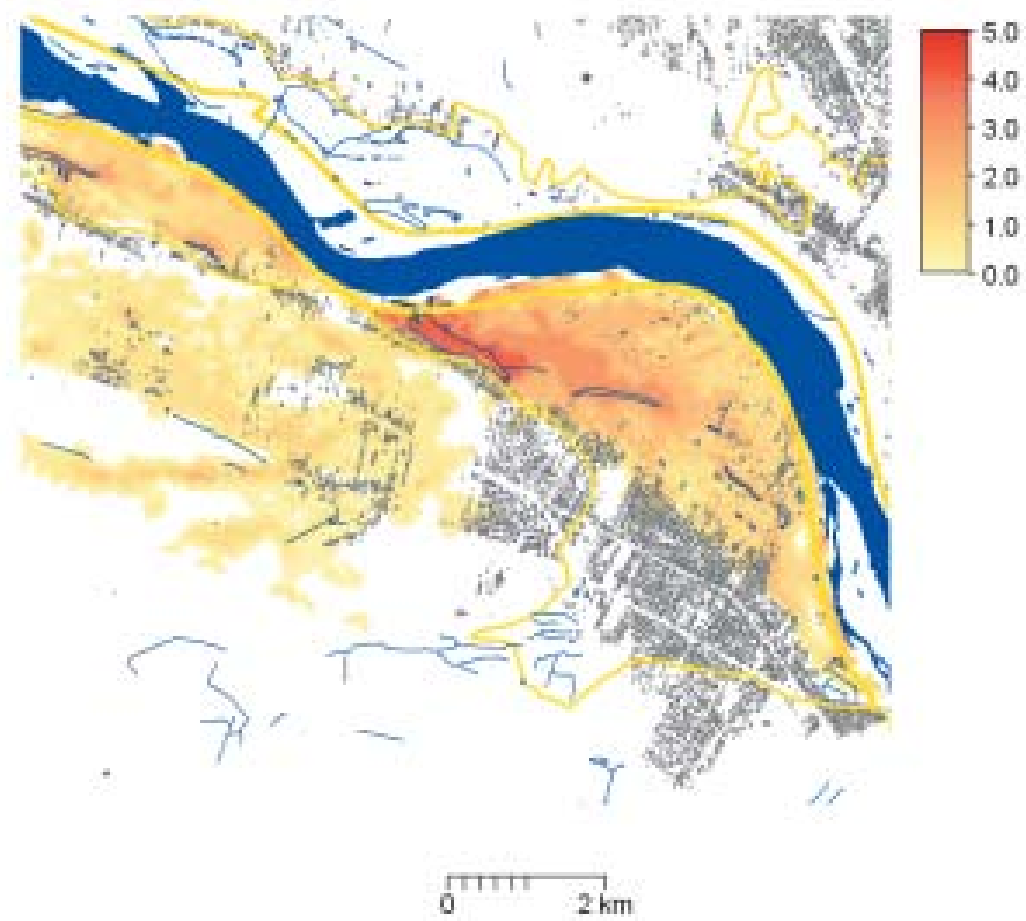

Figure 2a. Range of potential flooding due to a dike breach by $Q_{\mathrm{p}} 1 \%$ at Lomianki after $12 \mathrm{~h}$., colours represent depth of inundation, line shows range of inundation obtained from 1D model.

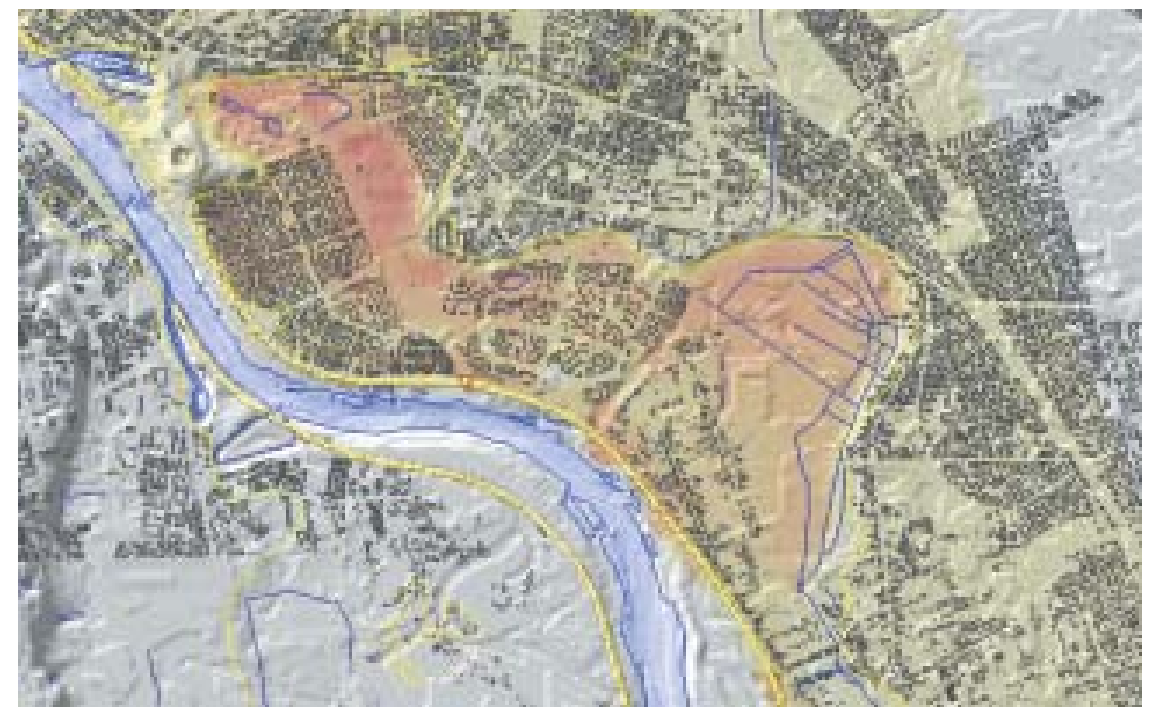

Figure 2b. Range of potential flooding due to dike breach by $Q_{\mathrm{p}} 1 \%$ at Saska Kępa after $12 \mathrm{~h}$., colours represent depth of inundation, line shows range of inundation obtained from 1D model. 


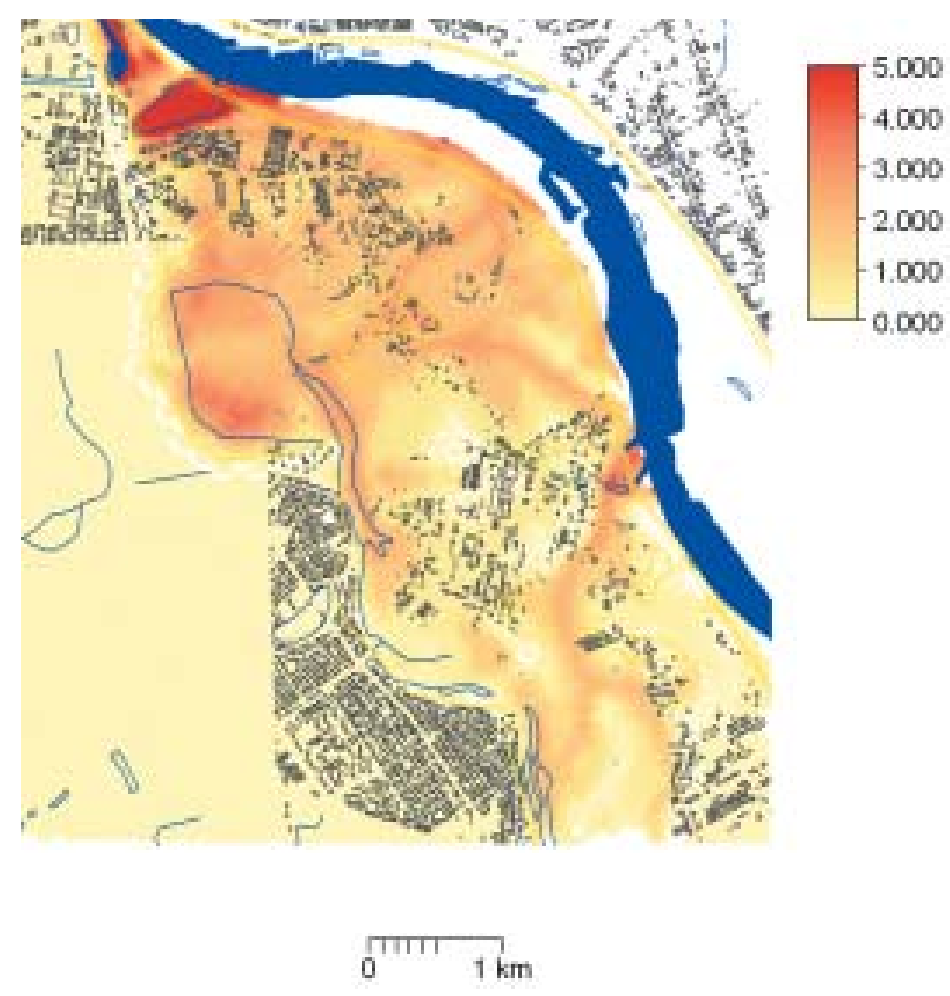

Figure 2c. Range of potential flooding due to dike breach by $Q_{\mathrm{p}} 1 \%$ at Wilanów after 12 h., colours represent depth of inundation, line shows range of inundation obtained from 1D model.

crossing the map of land cover with flood inundation depth after $12 \mathrm{~h}$. The accuracy of the buildings' geometry corresponds to the newest edition of topographic maps of Warsaw in the scale 1:10,000 and map datum 1992. This approach allows us to calculate the possible financial losses of a given potential flood by the application of the initial value of the buildings and depth damage curves. That approach is used in the USA by the Federal Insurance Administration (FIA) as "credibility weighted" depth-damage curves, as well as selected curves developed for various districts by the U.S. Army Corps of Engineers (USACE). It has been found that the most frequent depth of inundation in buildings on the studied areas in Warsaw is within the range of 0.5-1 $\mathrm{m}$ (Fig. 3).

Aggregated areas of inundated buildings as a result of a potential flood can be used together with the typical damage values worked out by Chojnacki (2000) for Polish conditions. Damage values for 5 different classes of settlement intensity have been estimated using actual flood damage costs after the 1997 flood in the Oder catchment.

\section{CONCLUSIONS}

Potential flood zone maps are very important when it comes to planning the concentration and the redistribution of a population within the process of growing urbanization. The two-dimensional hydraulic model of flooding is the best solution for analysing the spatial pattern of risk and the cost of flooding. The model shows the depth and duration of inundation, as well as the velocities and direction of the water flow. These parameters, when combined with 


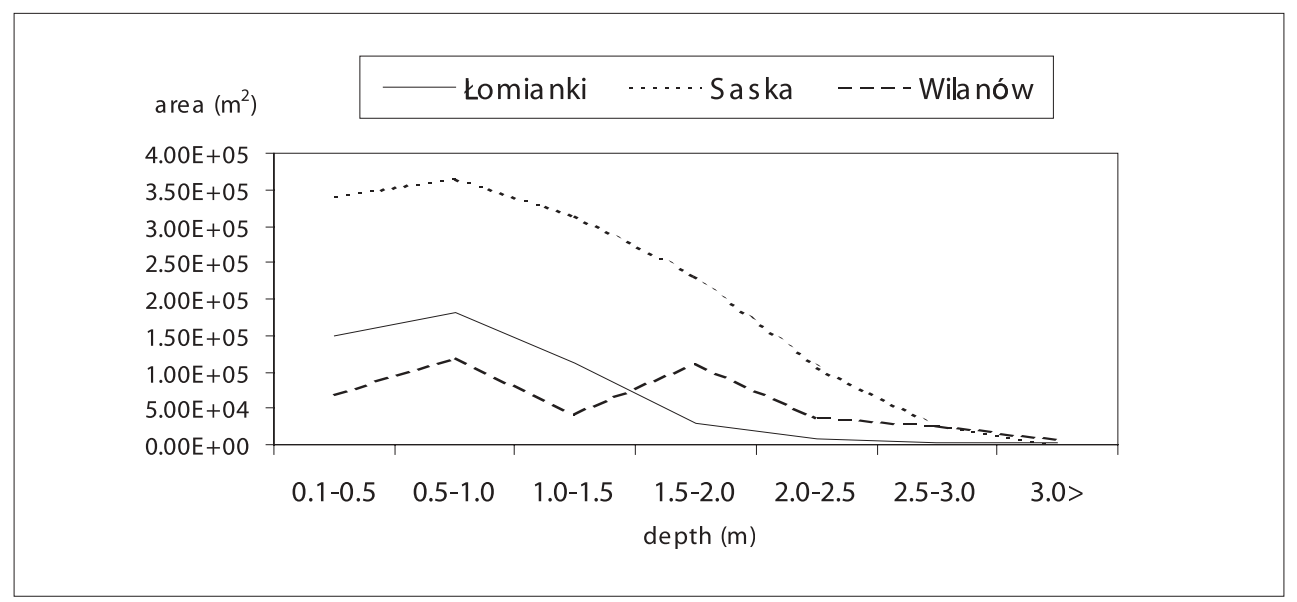

Figure 3. Area of buildings and depth of inundation caused by potential flood $Q_{1 \%}$ due to a dike breach after $12 \mathrm{~h}$ at selected districts of Warsaw.

the information on the height of buildings and their value, can give an approximation of flood costs in various different scenarios.

The most important information which has been obtained from the 2D model is the time that elapses from the dike breach and the moment at which a given point is inundated. The spatial distribution of this delay obtained from the 2D hydrodynamic model can be transformed into a cartographic representation, and as a propagation map can be used for the defining the risk in the flood zone.

\section{ACKNOWLEDGMENTS}

This paper presents results obtained in the project "Extreme hydrometeorological events in Poland and their impact - the European context", which has been financed by a grant from the Ministry of Sciences and Higher Education. We are grateful to the Global Land Cover Facility, the Institute for Advanced Computer Studies, University of Maryland, College Park, USA for making available to us the Landsat 7 image.

\section{REFERENCES}

Bogdanowicz, E., Fal, B. and Dobrzyńska, I. (2000), Charakterystyki hydrologicz- ne [Hydrological characteristics], in: Wista $w$ Warszawie [The Vistula River in Warsaw], Biuro Zarządu m.st. Warszawy. Wydział Planowania Przestrzennego i Architektury, Dom Wydawniczy Elipsa, Warszawa, 9-13.

Chen, A. S., Hsu, M. H., Chen, T. S. and Chang, T. J. (2005), An integrated inundation model for highly developed urban areas, $\mathrm{Wa}$ ter Science and Technology, 51 (2): 221-229.

Chojnacki, J. (2000), Szacowanie przewidywanych strat powodziowych w terenach zurbanizowanych metodą typizacji zagospodarowania obszarów zagrożonych [Evaluation of expected flood losses in an urban area using the method of land use classes], Gospodarka Wodna, 10: 368-373.

Cyberski, J., Grześ, M., Gutry-Korycka, M., Nachlik, E., and Kundzewicz, Z.W. (2006), History of floods on the River Vistula. Hydrological Sciences-Journal, Special issue: Historical Hydrology, 51 (5): 799-817.

Dewals, B., Archambeau, P., Ericum, S., Mouzelard, Th. and Pirotton, M. (2002), Dam-break hazard assessment with geomorphic flow computation, using WOLF 2D hydrodynamic software., in Brebbia, C.A. (eds.) Risk Analysis III. WIT Presss, Southampton, Boston, 59-68.

Drożdżal, E. (2006), Strefy zagrożenia powodziowego. [Zones of flood danger], Gospodarka Wodna, 11: 425-427. 
Fal, B. and Dąbrowski, P. (2001), Dwieście lat obserwacji i pomiarów hydrologicznych Wisły w Warszawie: Obserwacje stanów wody [Two hundred years of hydrological observations and measurements of the Vistula in Warsaw: Observations of water levels], Gospodarka Wodna, 11: 461-467.

Gutry-Korycka, M., Magnuszewski, A., Suchożebrski, J., Jaworski, W., Marcinkowski, M. and Szydłowski, M. (2006), Numerical estimation of flood zones in the Vistula River valley, Warsaw, Poland, in: Climate Variability and Change-Hydrological Impacts (Proceedings of the Fifth FRIEND World Conference held at Havana, Cuba, November 2006), IAHS Publ. 308, 191-195.

Grela, J., Kondziołka, K. and Radoń, R. (2006), Narzędzia wspomagające prace Ośrodka Kordynacyjno-Informacyjnego RZGW Kraków [Tools used to enhance the work of the RZGW Information and Coordination Center in Krakow], Gospodarka Wodna, 1: 9-13.

Haider, S., Paquier, A., Morel, R. and Champagne J. Y. (2003), Urban flood modelling using computational fluid dynamics, Water \& Maritime Engineering, 156 (2): 129-135.

Hański, A., Siudak, R., and Krukowski, T. (2006), Wykorzystanie GIS do szacowania zagrożenia powodziowego na przykladzie Poznania. [Use of GIS for flood risk estimation using the city of Poznan as a case study], in Gromiec, M. (ed.), Zastosowanie GIS w meteorologii i gospodarce wodnej, IMGW, Warszawa, 101-111.

Jacewicz, A. (2000), Ocena i propozycja zabudowy hydrotechnicznej koryta Wisty [The assessment and the proposal of the hydro-engineering development of the channel of the Vistula River], in: Wisła $w$ Warszawie, Wydział Planowania Przestrzennego i Architektury, Warszawa, 154-171.

Mark, O., Weesakul, S., Apirumanekul, C., Aroonnet, S.B. and Djordjevic, S. (2004), Potential and limitations of 1D modelling of urban flooding, Journal of Hydrology, 299 (3-4): 284-299.

Mitchell, J.K. (2003), European river floods in a changing world, Risk Analysis, (23) $3: 567-574$.
Nachlik, E., Kostecki, S., Gądek, W. and Stochmal, R. (2000), Strefy zagrożenia powodziowego [Flood hazard zones]. Wydawnictwo Profil - Biuro Koordynacji Projektu Banku Światowego, Wrocław.

Radczuk, L., Szymkiewicz, R., Jełowicki, J., Żyszkowska, W. and Brun, J. F. (2001), Wyznaczanie stref zagrożenia powodziowego [Determination of the zones of flood hazard], Wydawnictwo Safege - Biuro Koordynacji Projektu Banku Światowego, Wrocław.

Soczyńska, U., Magnuszewski, A., Nowicka, B., and Jełowicki, J. (2002), Floodplain inundation based on coupled hydraulic and GIS models, in van Lanen, H.A., Demuth, S. (eds.), Friend 2002 - Regional Hydrology: Bridging the Gap between research and practice, IAHS Publication 274: 131-137.

Sole, A. and Zuccaro, G. (2005), New urban area flood model: a comparison with MIKE11-quasi2d, Advances in Geosciences, 2: 279-284.

Szydłowski, M. (2001), Two-dimensional Shallow Water Model for Rapidly and Gradually Varied Flow, Archives of HydroEngineering and Environmental Mechanics, 48 (1): 35-61.

Szydłowski, M. (ed.) (2003), Matematyczne modelowanie hydraulicznych skutków awarii zapór wodnych [Mathematical modelling of dam-break hydraulic effects], Monografie Komitetu Gospodarki Wodnej Polskiej Akademii Nauk, 22.

Szydłowski, M. (2005), Numerical Simulation of Extreme Flooding in Built-up Area, Archives of Hydro-Engineering and Environmental Mechanics, 52 (4): 85-97.

Wierzbicki, J. (2001), Stałość pionowego układu koryta Wisty oraz położenia zwierciadta wód matych $i$ wielkich na odcinku miejskim $w$ Warszawie [Stability of the vertical setting of the channel of the Vistula and the position of the low and high discharges on the urban segment in Warsaw], Gospodarka Wodna, 4: 143-149.

Paper first received: September 2006 In final form: May 2009 
http://rcin.org.pl 